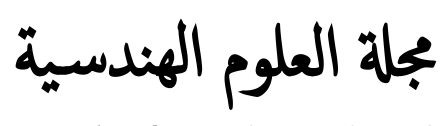

FES Journal of Engineering Sciences

http://journal.oiu.edu.sd/ojs/index.php/fjes/index

\title{
Mineralogical and Chemical Characterization of Bajrawia Iron Ore, Sudan
}

\section{A. ABBAKER ${ }^{1, *}$, E.M. MOSLIM ${ }^{1}$ and M.S. EL-SALMAWY ${ }^{2}$}

1 Mining Engineering Department, Omdurman Islamic University, Omdurman, Sudan

2 Faculty of Petroleum and Mining Engineering, Suez Canal University, Egypt

* Corresponding author: A. ABBAKER (e-mail: a7medelmubarak@yahoo.com ).

Article history: Received 18 January 2019, Received in revised form 24 March 2019, Accepted 27 March 2019

\begin{abstract}
In this contribution, the mineralogical and chemical characterization of Bajrawia iron ore was investigated. The chemical analysis was conducted using atomic absorption spectroscopy, X-ray Fluorescence, Energy Dispersive X-ray and titration. The mineralogical characterization was obtained by optical microscopy and X-ray diffraction. The physical properties such as densities, water content and porosity were determined. It has been found that Bajrawia iron ore contains about $35.5 \%$ Fe and some impurities like phosphorus and silica. SEM photo showed that the main minerals are goethite, clay minerals and quartz. The ore has low density because it has high porosity degree. This type of iron ore is disseminated in rock matrix and would be difficult to process.
\end{abstract}

Keywords: Iron ore, Chemical analysis, Mineralogical characterization, Physical properties.

\section{INTRODUCTION}

The Nubians of the Merowitic Kingdom at Bajrawia were among the first nations to produced iron from its natural ore at about 150 BC - 350 AC located in the Nile State between Shandi and Atbara Towns. They mined the ore from the area lying east of the Bajrawia pyramids. Their open pit mine is recently discovered for the first time by the geologists of Bajrawia Mining Company (BMC) [1].

Fig. 1 shows the geological map of study area and the distribution of iron oxide, also the ore east of the Nile is bounded by Kasala State borders and extend deeply in the western desert at the west, the coordinates are longitudes $33^{\circ} 10^{\prime}$ $00^{\prime \prime}-34^{\circ} 14^{\prime} 00^{\prime \prime}$ and latitudes $16000^{\prime} 00^{\prime \prime}-17^{\circ}$ $23^{\prime} 00^{\prime \prime} \mathrm{N}$.

Iron ore is the raw material for steel in which metallic iron is extracted from. The unique combination of steel makes it an ideal material for the construction industry, shipbuilding, motor vehicle manufacturer, railway construction, to ridge building, heavy industry, machinery manufacture and engineering applications [1].
The existence of even small amounts of some elements can make effects on the behavioural characteristics of iron or the operation of a smelter. These effects can be both good and bad, some catastrophically bad. Some chemicals are deliberately added such as flux which makes a blast furnace more efficient. Others are added because they make the iron more fluid, harder, or give it some other desirable quality [2].

The effective elements of iron ore as follow:

$$
\begin{aligned}
& >\text { Iron content: } 55 \%-68 \% \\
& >\text { Alumina: } 3.5 \%-5 \% \\
& >\text { Silica: } 4 \%-8 \% \\
& >\text { Phosphorus: } 0.07 \%-0.125 \% \\
& >\text { Sulphur: } 0.05 \%-0.07 \%
\end{aligned}
$$

The lack of knowledge about the mineralogical and chemical characterization of iron ore is a common problem at the iron processing and production [2]. Iron ores formed almost in all major geological environments, but the most important deposits are sedimentary as they supplied most iron ore worldwide. Iron occurs in 


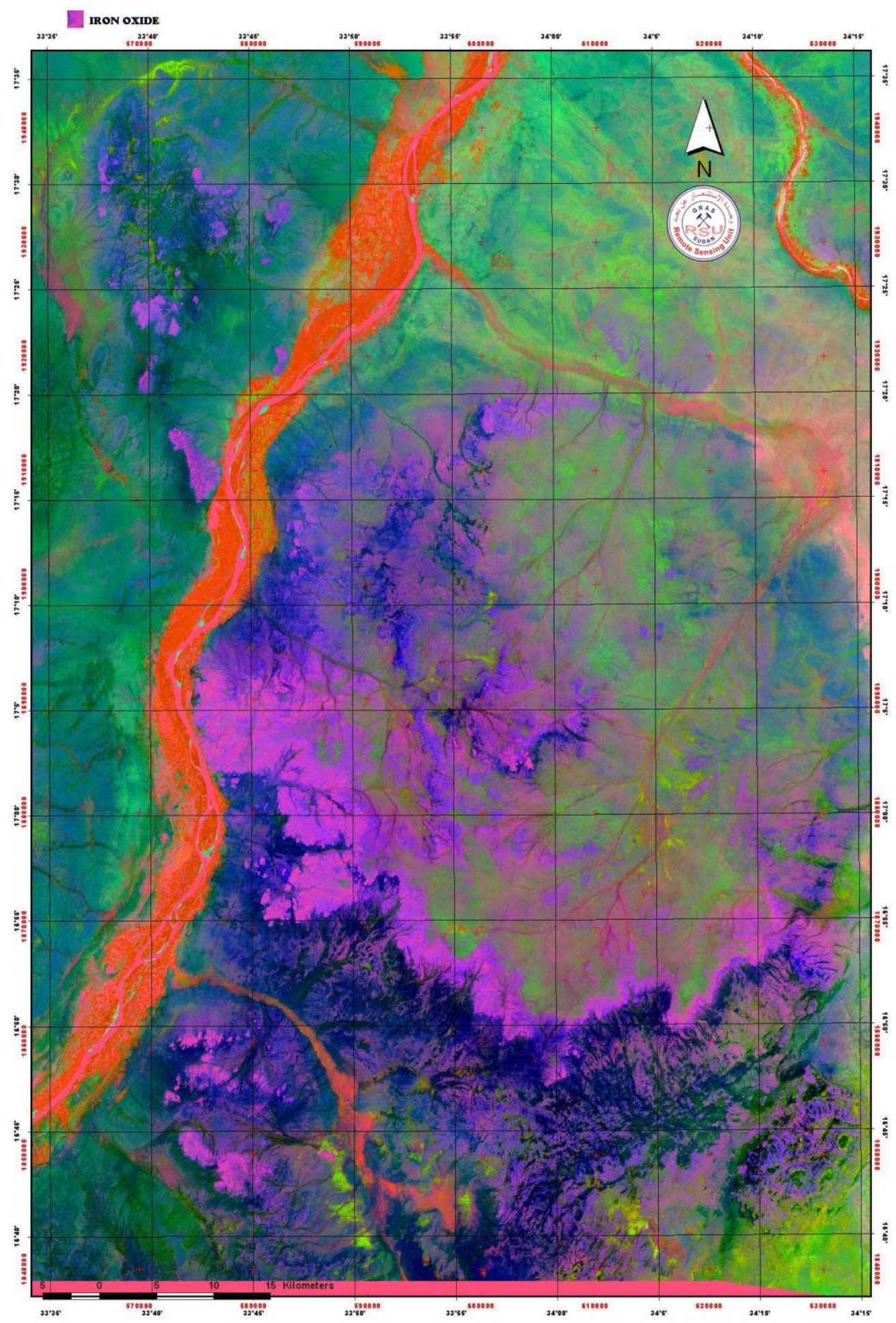

Fig. 1. Geological map of the study area

Iron oxide Grass and Trees Water

many different minerals, but only a few have a significant amount of the element and they make up the ores of higher value. The iron ores normally exist as oxides (hematite, magnetite and taconite), hydroxides (limonite, goethite and bog), carbonite (siderite), silicates (chamosite) and sulphide (pyrite) [3]. Total reserves were quickly estimated at around $(2.5-3)$ billion tons $[1,4]$
A very few literatures shed light on the metallogeny of this ore body. Schwarz and Germann (1993) studied the mineralization as part of the northern Sudan oolitic ironstones. They compared the oolites from marine environment (Wadi Halfa) with those of continental environment. They established chemical bases of discrimination between the 
two environments [5]. It has been mentioned briefly in Mohmed Ali et al. (2003) as an extension of Wadi Halfa ore body, the author considered it as a reserve of a huge steel plant. He mentioned they could have been formed under the same geological environments, for they share many common geological characteristics [6]. Abdel Mageed (2006), paid a visit to the site, and initiated an extensive campaign to promote an industrial steel installation based on this iron ore [7].

The main aim of this study is to improve the knowledge about the chemical, physical and mineralogical characteristics of the Bajrawia iron ore, in this article complete study about a chemical and mineralogical constitution and physical properties are presented.

\section{MATERIAL AND METHODS}

The iron ore samples have been taken from Bajrawia at the Nile State, Sudan. Trenches -which the samples have been collected frommade by Bajrawia Mining Company located $16^{\circ}$ $57^{\prime} 14.2^{\prime \prime} \mathrm{N}, 33^{\circ} 48^{\prime} 15.7^{\prime \prime}$ E. Trenches areas are about $(7.4 \times 2.4) \mathrm{m}^{2}$ and $428 \mathrm{~m}$ over the sea, in each side of the trenches six samples have been taken and recorded their information.

\section{A. Sample preparation}

The ore samples were crushed by laboratory jaw crusher and roll crusher then screened, the crushed samples over $5 \mathrm{~mm}$ return into the closed circuit, the product was mixed with coning and quartering method as shown in Fig. 2. Bulk samples directed to prepare polish and thin sections for microscope studies as well as physical properties.

\section{B.Optical microscopy}

Light polarized microscopy using a petrographic polarizing Nikon Eclipse E100 microscope with a digital camera and OLYMPUS BX51 were used to identify the mineralogical composition of geological materials in order to reveal their origin and evolution. The microscope observations were performed using both transmitted and reflected light modes.

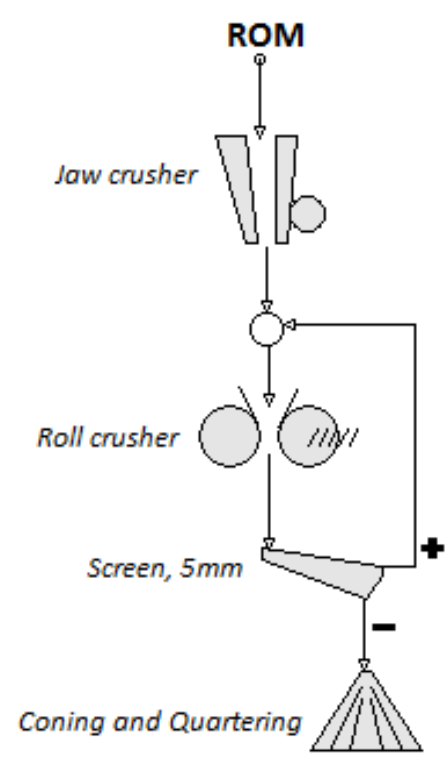

Fig. 2. Flowsheet chart of sample preparation

\section{X-ray Diffraction}

X-ray diffraction analysis (XRD) was carried out to identify the major mineral components of the sample and also used to quantify the proportions of different minerals.

\section{X-ray Fluorescence}

$X$-ray fluorescence spectrometer (XRF) used to determine the elemental composition of materials.

\section{E.SEM- EDX}

Scanning Electron Microscope with Energy Dispersive X-ray Spectroscopy (SEM-EDX) is a technique for analyzing the elements present near the surface of a selected microscopic region of a sample and give a spectacular image.

\section{F. Atomic Absorption Spectroscopy}

Atomic absorption spectroscopy (AAS) is used as a Spectro-analytical procedure for the quantitative determination of chemical elements using the absorption of optical radiation (light) by free atoms in the gaseous state.

\section{G. Physical properties}

For physical properties, five samples were cut into small pieces $\left(5-10 \mathrm{~cm}^{3}\right)$ and smoothed at the end of their surfaces with parallelism. The nature weight $\left(\mathrm{W}_{\mathrm{n}}\right)$, saturated weight $\left(\mathrm{W}_{\mathrm{w}}\right)$, saturated-submerged weight $\left(\mathrm{W}_{\mathrm{s}}\right)$ and dry weight $\left(\mathrm{W}_{\mathrm{o}}\right)$ of samples were weighted using a balance with accuracy $0.001 \%$ and then applied into equations below [8]. 


$$
\begin{gathered}
\text { Natural density }=\frac{W n}{W w-W s} \\
\text { Dry density }=\frac{W 0}{W w-W s} \\
\text { Saturated density }=\frac{W w}{W w-W s} \\
\text { Natural water content }=\left[\frac{W n-W o}{W 0}\right] \times 100 \% \\
\text { Saturated water content }=\left[\frac{W w-W o}{W 0}\right] \times 100 \% \\
\text { Porosity, } n=\left[\frac{W w-W o}{W w-W s}\right] x 100 \% \\
\text { The degree of saturation }=\left[\frac{W n-W 0}{W w-W 0}\right] \times 100 \% \\
\text { Void ratio }=\left[\frac{n}{1-n}\right]
\end{gathered}
$$

\section{RESULTS AND DISCUSSION}

\section{A. Chemical Characterization}

The chemical analysis of Bajrawia iron ore representative sample using XRF is shown in Table 1 . The sample contains $35.7 \%$ of $\mathrm{Fe}$, which is a very low grade in nature. The major impurities are $\mathrm{SiO}_{2}(30.5 \%), \mathrm{Al}_{2} \mathrm{O}_{3}(11.8 \%)$ and $\mathrm{P}_{2} \mathrm{O}_{5}(0.849 \%)$. The AAS and titration analysis was confirmed that the sample contains $35.12 \%$ and $36.12 \%$ respectively. The result of SEM-EDX in Fig. 3 showed that the sample contained also $35.33 \% \mathrm{Fe}, 0.32 \% \mathrm{P}, \mathrm{Si}$ and $\mathrm{Al}$. Moreover, the main minerals are goethite, clay minerals and quartz.

Table 1. Average Chemical analysis of Bajrawia iron ore sample

\begin{tabular}{cc}
\hline Element & Assay \% \\
\hline $\mathrm{Fe}_{2} \mathrm{O}_{3}$ & 51.034 \\
$\mathrm{Fe}$ & 35.72 \\
$\mathrm{SiO}_{2}$ & 30.456 \\
$\mathrm{Al}_{2} \mathrm{O}_{3}$ & 11.810 \\
$\mathrm{CaO}$ & 1.297 \\
$\mathrm{P}_{2} \mathrm{O}_{5}$ & 0.849 \\
$\mathrm{P}$ & 0.370 \\
$\mathrm{SO}_{3}$ & 0.240 \\
$\mathrm{TiO}_{2}$ & 0.538 \\
$\mathrm{Mn}_{3} \mathrm{O}_{4}$ & 0.554 \\
$\mathrm{Others}$ & 3.439
\end{tabular}

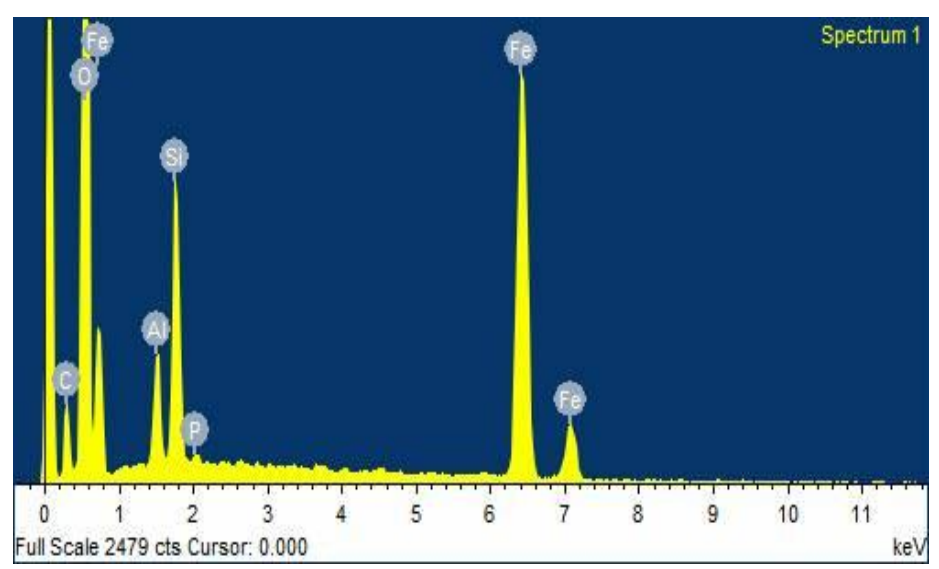

Fig. 3. SEM-EDX of the iron ore representative sample

According to those results of chemical analysis, it is clear that the Bajrawia iron ore contains about $35.5 \% \mathrm{Fe}$ and require beneficiation by removing the impurities such as silica and phosphorus to meet the international specifications of the steel industry.

\section{B.Mineralogical Characterization}

From the XRD diffractogram is shown in Fig. 4 goethite and hematite have occurred as iron-bearing mineral, but goethite is more than hematite. Kaolinite is the aluminum bearing silicate gangue phase and quartz is the silica mineral. From microscope study, it is observed that iron oxide filling -pore- the spaces between rounded to sub-rounded quartz grains (i.e. not subjected to transportation from its source) and brown clayey fragments which indicate that iron oxide is the sedimentary origin. The iron ore mainly contains goethite and few of hematite, kaolinite (clay) also was observed, as in Figs. 5 to 8. Iron ore sample is disseminated and contains a small grains size of silica with an average size of $45 \mu \mathrm{m}$ (as seen in Fig. 8 and 10). This characteristic reveals that this iron ore is difficult to process one. In Fig. 11, the SEM image of the polished cross-section of iron ore sample showing heterogeneous texture with quartz (light-grey), iron oxides (white) and aluminosilicate minerals (light-grey). The black spots confirm that the iron ore sample has a high degree of porosity. 


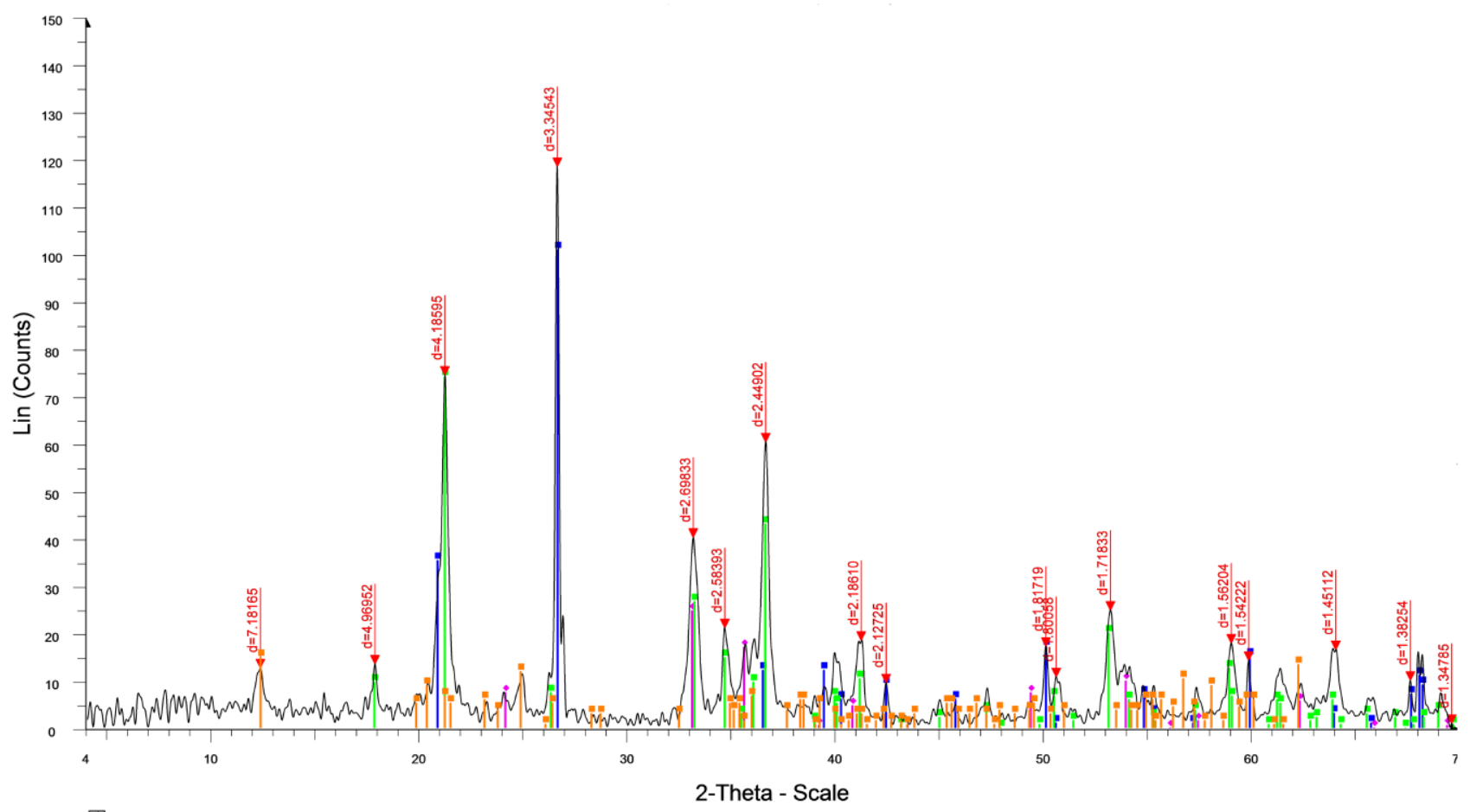

WD: Aabdallaliron ore Al Amin.RAW - File: iron ore Al Amin.RAW - Type: 2 Th/Th locked - Start: $3.844^{\circ}$ - End: $69.872^{\circ}$ - Step: $0.020^{\circ}$ - Step time: $0.4 \mathrm{~s}$ - Temp.: $25^{\circ} \mathrm{C}$ (Room) - Time Started: $0 \mathrm{~s}$ - 2-Theta: $3.844^{\circ}$ - Theta: 2 Operations: Displacement 0.296 | Displacement 0.128 | Displacement 0.016 | Displacement 0.072 | Displacement 0.296 | Displacement 0.408 | 5

$\square 05-0490$ (D) - Quartz, low - SiO2 - Y: $85.12 \%$ - $d$ x by: 1 - WL: 1.5406 - Hexagonal - I/lc PDF 3.6 - S-Q $36.3 \%$ -

89-0598 (C) - Hematite, syn - Fe2O3 - Y: $20.83 \%$ - d x by: 1. - WL: 1.5406 - Rhombohedral - I/c PDF 3.2 - S-Q $10.0 \%$

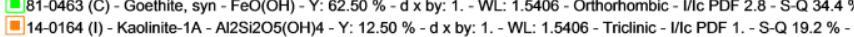

Fig. 4. XRD pattern of the iron sample

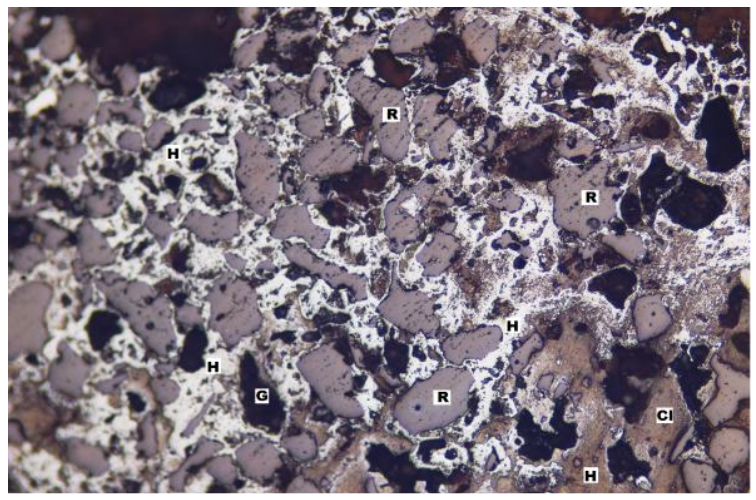

Fig. 5. Hematite $(\mathrm{H})$ the main constituent of coarse metallic fragments within the non-metallic clayey matrix $(\mathrm{Cl})$, dark brown goethite grains $(\mathrm{G})$.

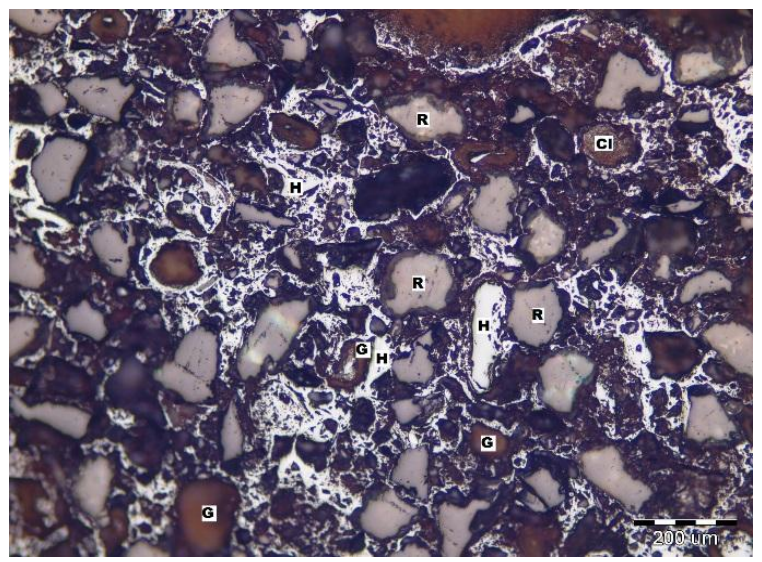

Fig. 7. Hematite groundmass $(\mathrm{H})$ as pore-filling between the rounded and brown clayey fragments $(\mathrm{R})$. coarse-grained dark brown goethite grains frequently observed $(G)$.

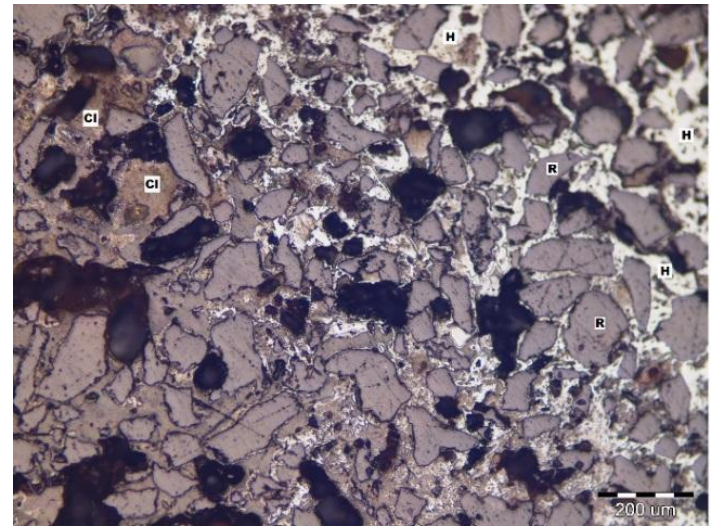

Fig. 6. Disseminated hematite $(\mathrm{H})$ within the non-metallic clayey matrix $(\mathrm{Cl})$, Brown non-metallic groundmass $(\mathrm{Cl})$ contains dark brown goethite grains $(\mathrm{G})$.

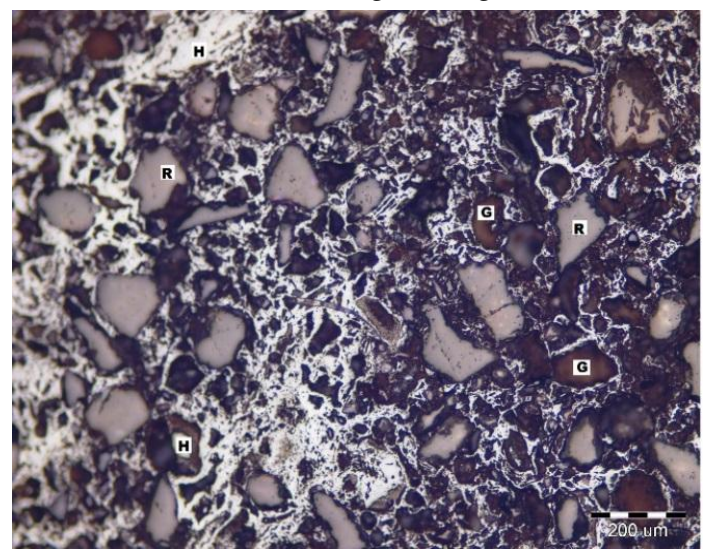

Fig. 8. Coarse-grained non-metallic fragment $(R)$ with enclosed within the hematite-rich matrix $(\mathrm{H})$, Goethite $(\mathrm{G})$ and detrital quartz $(\mathrm{Q})$ within the clayey fragment $(\mathrm{R})$. 


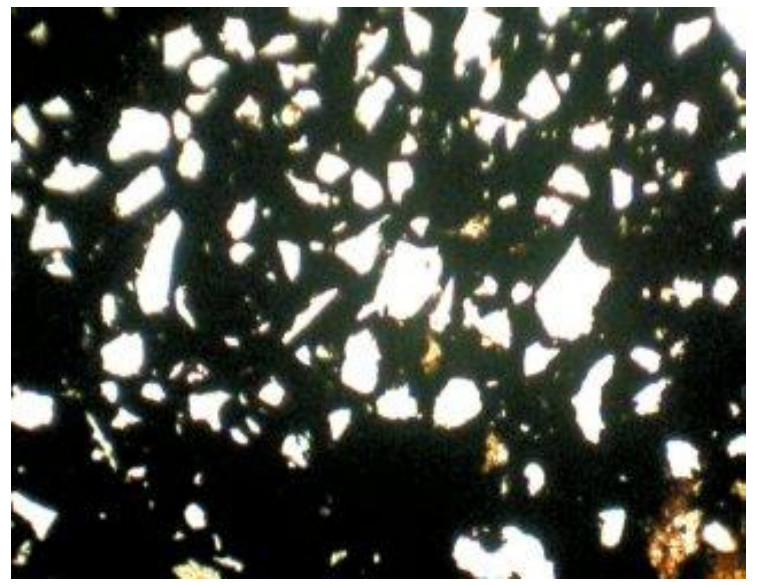

Fig. 9. Photomicrograph shows angular quartz grains under Plane Polarized Light X4

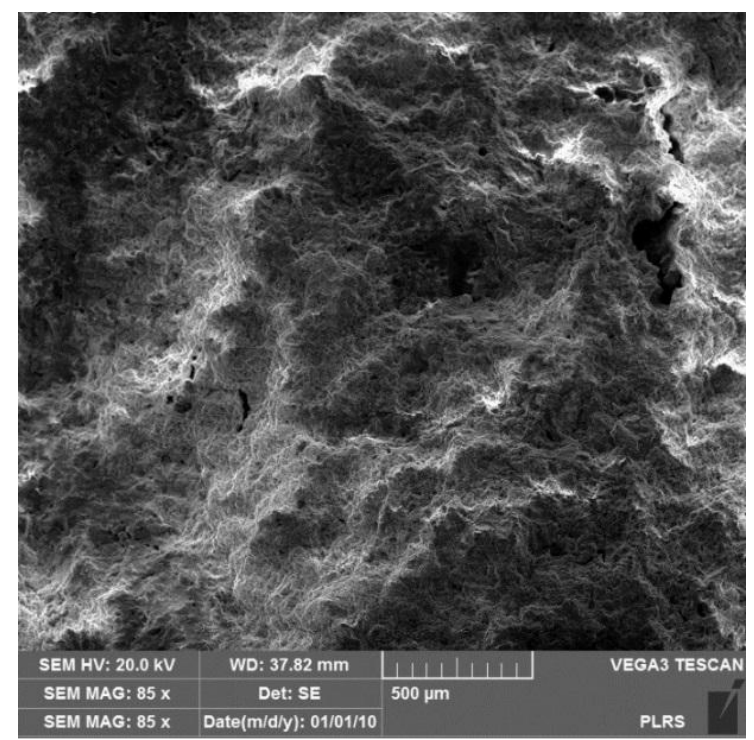

Fig. 11. SEM image of the iron ore sample

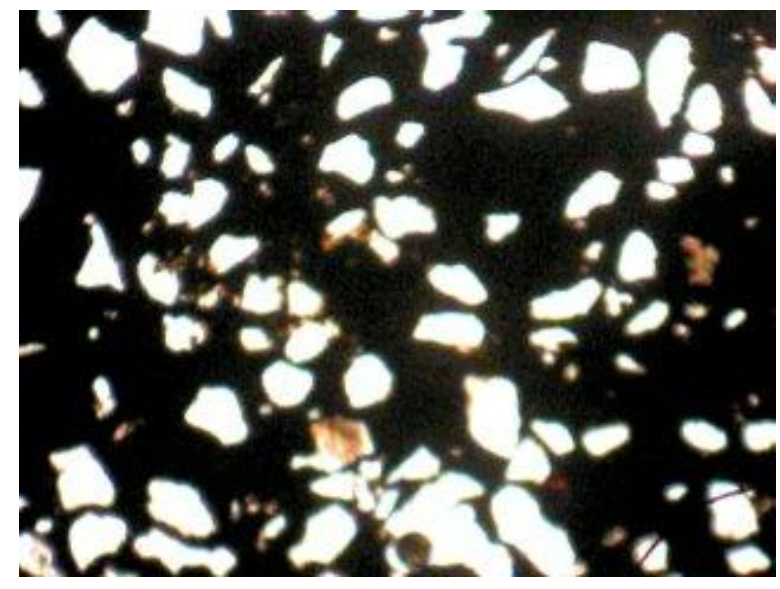

Fig. 10. Photomicrograph shows slightly oriented quartz grains under Plane Polarized Light X4

\section{Physical Properties}

From Table 2. (below) it is clear that the iron ore has low density in all three types (natural, dry, saturated) due to the high percentage of an emptiness. The colour of the sample is rusted-yellow which indicated that the sample is goethite (Bog, Limonite) containing a respectful amount of clay and silica.

Table 2. Physical properties of Iron ore

\begin{tabular}{|c|c|c|c|c|c|c|c|c|c|c|c|}
\hline $\begin{array}{c}\text { Sample } \\
\text { code }\end{array}$ & $\begin{array}{c}\text { Natural } \\
\text { weight } \\
\text { (g) }\end{array}$ & $\begin{array}{l}\text { Weight } \\
\text { in water } \\
\text { (g) }\end{array}$ & $\begin{array}{l}\text { Saturated } \\
\text { weight } \\
\text { (g) }\end{array}$ & $\begin{array}{l}\text { Dry } \\
\text { weight } \\
\text { (g) }\end{array}$ & $\begin{array}{l}\text { Natural } \\
\text { Density } \\
\left(\mathrm{g} / \mathrm{cm}^{\mathbf{3}}\right)\end{array}$ & $\begin{array}{c}\text { Dry } \\
\text { Density } \\
\left(\mathbf{g} / \mathrm{cm}^{\mathbf{3}}\right)\end{array}$ & $\begin{array}{l}\text { Saturated } \\
\text { Density } \\
\left(\mathrm{g} / \mathrm{cm}^{3}\right)\end{array}$ & $\begin{array}{c}\text { Natural } \\
\text { Water } \\
\text { Content } \\
\%\end{array}$ & $\begin{array}{c}\text { Degree of } \\
\text { Saturation } \\
\%\end{array}$ & $\%$ & $\begin{array}{l}\text { Void } \\
\text { Ratio }\end{array}$ \\
\hline S1 & 137.1 & 93.9 & 154.9 & 135.6 & 2.25 & 2.22 & 2.54 & 1.11 & 7.80 & 31.64 & 0.46 \\
\hline S2 & 56.4 & 39.5 & 64.9 & 55.9 & 2.22 & 2.20 & 2.56 & 0.82 & 5.12 & 35.41 & 0.55 \\
\hline S3 & 93.1 & 56.2 & 105.6 & 91.9 & 1.88 & 1.86 & 2.14 & 1.21 & 8.17 & 27.60 & 0.38 \\
\hline S4 & 91.8 & 64.4 & 104.1 & 90.7 & 2.31 & 2.29 & 2.62 & 1.21 & 8.21 & 33.70 & 0.51 \\
\hline S5 & 166.1 & 115.6 & 187.7 & 163.2 & 2.30 & 2.26 & 2.60 & 1.79 & 11.93 & 34.00 & 0.52 \\
\hline \multicolumn{5}{|c|}{ Average } & 2.19 & 2.17 & 2.49 & 1.23 & 8.25 & 32.47 & 0.48 \\
\hline
\end{tabular}




\section{CONCLUSIONS}

The Bajrawia iron ore has a low grade of iron and high phosphorus content which requires beneficiation before used in steel making. Goethite accounts about $77 \%$ of total iron and hematite about $23 \%$. kaolinite, phosphorus and quartz are the major impurities. Iron ore sample is disseminated and contains a small grains size of silica with an average size of $45 \mu \mathrm{m}$ which make it very hard to liberate, hence the Bajrawia iron ore is difficult to treat. Moreover, the Bajrawia iron ore has a high degree of porosity which reflected in the density.

\section{ACKNOWLEDGEMENTS}

The authors wish to thank Ms. Salah and Ms. Morshed for sample preparation. The author's gratitude is extended to Dr O. Satti and Prof. M. Talballa for their help at various stages of this work.

\section{REFERENCES}

1. Ahmed, A.A.M., et al. (2010), Bajrawia Iron Ore Deposits Geology, Grade and Reserve Estimation.

2. index, T.s. methodology and specifications, iron ore index. 2010.

3. Chatterjee, K.K. (2007), Uses of metals and metallic minerals: New Age International.

4. Wadelnour, N.E., et al. (2014), The Bagrawiya Oolitic Iron Ore Deposit and A Comparison with Wadi Halfa
Ore, North Sudan: The Geological Research Authority of The Sudan.

5. Schwarz, T., Germann, K. (1993) Oolitic ore stones in continental sediments of Northern Sudan. In: Geoscientific Research in NE-Africa. Thorweihe \& Schandelmeier (eds.). Balkema, Rotterdam.

6. Mohmed Ali, N., W., El Amin, M., B., El Tayeb, H., Haroun, A. (2003) A study on the oolitic iron ore mineralization of Wadi Halfa, GRAS report.

7. Abdel Mageed, A. (2006) Proposal for establishing steal industry in Shendi-Ed Damer area, The River Nile State (Hasa construction and Mining Co. Ltd., Khartoum), 38P.

8. Schön, J.H. (2015), Physical properties of rocks: Fundamentals and principles of petrophysics. Vol. 65: Elsevier.

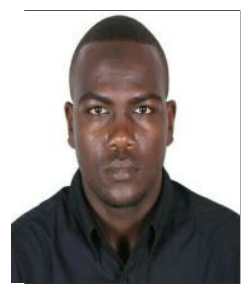

Ahmed Mohammedelmubarak Ahmed Abbaker was born in Omdurman, Sudan on September $30^{\text {th }}, 1993$. He earned a B.Sc. in Mining Engineering in 2015 from Omdurman Islamic University, Omdurman, Sudan. In late 2018, he got a M.Sc. in Mineral processing form the same university.

He worked as a teaching assistant in Mining department at the faculty of Engineering Sciences of Omdurman Islamic University since 2015 up to date 